\title{
ANALISIS HUBUNGAN ANTARA KARAKTERISTIK PEKERJA DENGAN STRES KERJA PADA PEKERJA PT LTI YANG BEKERJA DARI RUMAH SELAMA MASA PANDEMI COVID-19 TAHUN 2021
}

\author{
Amita Rahma Shintyar ${ }^{1}$, Baiduri Widanarko ${ }^{2}$ \\ Magister Keselamatan dan Kesehatan Kerja, Fakultas Kesehatan Masyarakat, Universitas Indonesia ${ }^{1}$ \\ Departemen Keselamatan dan Kesehatan Kerja, Fakultas Kesehatan Masyarakat, Universitas \\ Indonesia ${ }^{2}$ \\ amitarahmaa@gmail.com¹, baiduri@ui.ac.id ${ }^{2}$
}

\begin{abstract}
Job stress is a condition that causes employees to feel pressured, bored, and uncomfortable when doing work. About 50-60\% of all lost workdays are caused by work stress and this number is increased in Europe. Since the outbreak of COVID-19, all countries in the world have started implementing WFH (work from home). Due to the urgency of the situation, WFH can potentially be a stressor for workers. This study aims to analyze the level of work stress and provide an overview of the relationship between characteristics and work stress. This study used a cross sectional approach using the NIOSH Generic Job Stress Questionnaire and distributed using G-form to 62 respondents. As many as 62,9\% of respondents experienced mild work stress. The variables that were shown to have a significant relationships with work stress in this study were age, child's age, the working period, and work location.
\end{abstract}

Keyword $\quad$ : Work Related Stress, WFH, NIOSH

\begin{abstract}
ABSTRAK
Stres kerja adalah kondisi yang menyebabkan karyawan merasa tertekan, bosan, dan tidak nyaman dalam melakukan pekerjaannya. Sekitar 50-60\% dari hari kerja yang hilang disebabkan oleh stres kerja dan jumlah ini cenderung meningkat di Eropa. Semenjak merebaknya COVID-19, seluruh negara di dunia mulai memberlakukan Work from Home (WFH) atau bekerja dari rumah. Oleh karena situasi yang mendesak, WFH dapat berpotensi menjadi stressor bagi pekerja. Penelitian ini bertujuan untuk menganalisis tingkat stres kerja dan memberikan gambaran hubungan antara karakteristik pekerja dengan stres kerja pada pekerja PT LTI yang bekerja dari rumah selama masa pandemic COVID-19. Penelitian ini menggunakan pendekatan cross sectional dengan menggunakan kuesioner stres kerja NIOSH Generic Job Stres Questionnaire yang didistribusikan secara daring kepada 62 responden. Sebanyak $62,9 \%$ responden mengalami stres kerja ringan. Variabel yang terbukti memiliki hubungan yang signifikan dengan stres kerja pada penelitian ini adalah usia, usia anak, masa kerja, dan lokasi kerja.
\end{abstract}

Kata Kunci : Stres Kerja, WFH, NIOSH

\section{PENDAHULUAN}

Stres kerja adalah kondisi yang menyebabkan karyawan merasa tertekan, bosan, dan tidak nyaman dalam melakukan pekerjaannya. Stres terkait pekerjaan dapat disebabkan oleh organisasi kerja yang buruk, desain kerja yang buruk, manajemen yang buruk, kondisi pekerjaan yang tidak memuaskan dan kurangnya dukungan dari rekan kerja serta supervisor (World Health
Organization, 2020). stres adalah masalah kesehatan terkait pekerjaan kedua yang paling sering dilaporkan di Eropa. Sekitar 50-60\% dari semua hari kerja yang hilang disebabkan oleh stres terkait pekerjaan dan jumlah orang yang menderita kondisi ini cenderung meningkat (Mungkasa, 2020).

Tahun 2020 telah membawa perubahan yang belum pernah terjadi sebelumnya pada ekonomi global dan dunia kerja. 
Semenjak merebaknya COVID-19 di Wuhan, seluruh negara di dunia mulai menerapkan tindakan pencegahan penyebaran COVID-19, salah satunya adalah dengan perubahan metode kerja (Mungkasa, 2020). Perubahan metode kerja yang dimaksud adalah perubahan organisasi dalam memberikan tugas dan tanggungjawab kepada karyawannya dengan melarang karyawannya untuk bekerja di kantor dan berkumpul di sebuah ruangan. Larangan ini bukan dimaksudkan untuk merusak kinerja organisasi melainkan untuk mencegah penyebaran COVID-19. Work from home (WFH) atau atau bekerja dari rumah merupakan salah satu solusi yang digunakan perusahaan dalam menanggulangi wabah virus corona.

WFH sendiri dapat diartikan dengan bekerja dari jarak jauh, lebih tepatnya bekerja dari rumah, sehingga pekerja tidak perlu datang ke kantor untuk menyelesaikan pekerjaannya (Ramadhan \& Faruq, 2020). Oleh karena situasi yang mendesak, dalam pelaksanaannya WFH belum sepenuhnya dipahami oleh para pekerja, masih ada tempat untuk beristirahat sedangkan pekerjaan umumnya dilakukan di kantor. Kondisi ini terkadang menimbulkan konflik dalam keluarga meskipun WFH menciptakan fleksibilitas waktu dan tempat Hal ini dapat berpotensi menjadi sumber stressor bagi pekerja pada umumnya (McCloskey, 2018).

Beberapa peraturan terkait WFH ini sendiri telah dikeluarkan oleh beberapa daerah, seperti: Pergub DKI Jakarta no. 88 tahun 2020 mengenai Pelaksanaan Pembatasan Sosial Berskala Besar (PSBB) dalam penanganan COVID-19 di Provinsi Daerah Ibukota Jakarta dan Pergub Jawa Barat no. 46 tahun 2020 tentang Pedoman Pembatasan Sosial Berskala Besar Secara Proposional Sesuai Level Kewaspadaan Daerah Kabupaten/Kota Sebagai Persiapan Pelaksanaan Adaptasi Kebiasaan Baru Untuk Pencegahan dan Pengendalian Corona Virus Disease 2019 (COVID-19).

Penelitian (Song \& Gao, 2019) mengenai kesejahteraan antara pekerja yang bekerja di rumah dan bekerja di tempat kerja telah dilakukan. Didapati hasil bahwa pekerja yang memiliki peran ganda sebagai orang tua cenderung mengalami stres kerja dibandingkan dengan pekerja yang belum menikah atau yang sudah menikah namun belum memiliki anak. Hal ini lebih dominan dirasakan oleh pekerja wanita dikarenakan pekerja wanita cenderung memiliki peran yang lebih signifikan saat berada dirumah dibandingkan dengan pekerja laki-laki. Dalam penelitian ini juga disebutkan bahwa pekerja laki-laki dinilai lebih produktif dalam melakukan pekerjaannya saat berada di kantor daripada saat bekerja di rumah. Selain itu, salah satu penelitian juga menyebutkan bahwa COVID-19 mengakibatkan stres dikarenakan adanya perselisihan pengasuhan anak dan masalah orangtua yang dihadapi (Daks, Peltz, \& Rogge, 2020).

Penelitian ini dilakukan untuk menganalisis tingkat stres kerja dan hubungan antara karakteristik individu (jenis kelamin, usia, status pernikahan, jumlah anak, usia anak, masa kerja, jabatan dan lokasi kerja) dengan stres kerja pada pekerja PT LTI yang bekerja dari rumah atau work from home selama masa pandemic COVID-19.

\section{METODE}

Penelitian ini adalah penelitian deskriptif analitik dengan pendekatan potong lintang. Penelitian ini dilakukan di PT LTI yang berlokasi kerja di Jakarta dan Bandung. Sampel dari penelitian ini sebanyak 62 responden.

Data yang digunakan yaitu data primer dengan menggunakan kuesioner stres kerja NIOSH Generic Job Stress Questionnaire yang terdiri dari 158 pertanyaan. Kuesioner distribusikan secara daring menggunakan Google Form. Stres kerja dikelompokkan menjadi tiga kategori, yaitu stres kerja ringan (skor <40\%), stres kerja sedang (skor 40\%-75\%), dan stres kerja berat (skor $>75 \%)$. 
Data dianalisis secara deskriptif, dengan menampilkan frekuensi untuk mendeskripsikan distribusi frekuensi dan presentase masing-masing variabel independent (karakteristik pekerja, yaitu: jenis kelamin, usia, status pernikahan, jumlah anak, usia anak, masa kerja, jabatan dan lokasi kerja) dan variabel dependent (stres kerja). Analisis inferensial dengan metode uji chi-square dilakukan untuk mengetahui hubungan antara dua variabel (bivariat), yaitu masing-masing karakteristik pekerja dengan stres kerja.

\section{HASIL}

\section{Analisis Deskriptif}

Analisis univariat dilakukan terhadap karakteristik pekerja yang terdiri dari jenis kelamin, usia, status pernikahan, jumlah anak, usia anak, masa kerja, jabatan, dan lokasi kerja dengan stres kerja.

Table 1. Deskripsi Karakteristik dan Tingkat Stres Pekerja

\begin{tabular}{|c|c|c|}
\hline & Frequency & Percent \\
\hline \multicolumn{3}{|l|}{ Jenis Kelamin } \\
\hline Laki - laki & 43 & $69,4 \%$ \\
\hline Perempuan & 19 & $30,6 \%$ \\
\hline \multicolumn{3}{|l|}{ Usia } \\
\hline $20-25$ tahun & 17 & $27,4 \%$ \\
\hline $26-31$ tahum & 22 & $35,5 \%$ \\
\hline $32-37$ tahun & 11 & $17,7 \%$ \\
\hline $38-43$ tahun & 3 & $4,8 \%$ \\
\hline $44-49$ tahun & 1 & $1,6 \%$ \\
\hline $50-55$ tahun & 7 & $11,3 \%$ \\
\hline $56-61$ tahun & 1 & $1,6 \%$ \\
\hline \multicolumn{3}{|l|}{ Status Pernikahan } \\
\hline Belum menikah & 25 & $40,3 \%$ \\
\hline menikah & 37 & $59,7 \%$ \\
\hline \multicolumn{3}{|l|}{ Jumlah Anak } \\
\hline $\begin{array}{l}\text { Tidak memiliki } \\
\text { anak }\end{array}$ & 32 & $51,6 \%$ \\
\hline$\leq 2$ anak & 22 & $35,5 \%$ \\
\hline$>2$ anak & 8 & $12,9 \%$ \\
\hline \multicolumn{3}{|l|}{ Usia Anak } \\
\hline $\begin{array}{l}\text { Tidak memiliki } \\
\text { anak }\end{array}$ & 32 & $51,6 \%$ \\
\hline$<12$ tahun & 24 & $38,7 \%$ \\
\hline$\geq 12$ tahun & 6 & $9,7 \%$ \\
\hline \multicolumn{3}{|l|}{ Masa Kerja } \\
\hline$<4$ tahun & 49 & $79 \%$ \\
\hline$\geq 4$ tahun & 13 & $21 \%$ \\
\hline \multicolumn{3}{|l|}{ Jabatan } \\
\hline Direktur & 3 & $4,8 \%$ \\
\hline
\end{tabular}

\begin{tabular}{lcc} 
Kepala Divisi & 4 & $6,5 \%$ \\
Menejer & 6 & $9,7 \%$ \\
Staff & 49 & $79 \%$ \\
\hline Lokasi Kerja & & \\
Jakarta & 45 & $72,6 \%$ \\
Bandung & 9 & $14,5 \%$ \\
Jakarta dan & 8 & $12,9 \%$ \\
Bandung & & \\
\hline Stres Kerja & & \\
Ringan & 39 & $62,9 \%$ \\
Sedang & 21 & $33,9 \%$ \\
Berat & 2 & $3,2 \%$ \\
\hline
\end{tabular}

Sebagian besar dari total 62 responden, adalah laki-laki $(69,4 \%)$, berusia $26-31$ tahun $(35,5 \%)$, sudah menikah $(59,7 \%)$, dan tidak memiliki anak (51,6\%). Dari 30 responden yang memiliki anak, 24 responden $(38,7 \%)$ memilki anak dengan usia $<12$ tahun. Karakterisik lain adalah sebagian besar responden memiliki masa kerja <4 tahun (79\%), memiliki jabatan sebagai staf $(79 \%)$ dan bekerja di kantor pusat Jakarta $(72,6 \%)$.

Berdasarkan tingkat stres kerja, dari 62 responden, sebanyak 39 responden mengalami stres kerja ringan atau sebesar $62,9 \%, 21$ responden mengalami stres kerja sedang atau sebesar 33,9\% dan 2 responden mengalami stres kerja berat atau sebesar $3,2 \%$.

\section{Analisis Inferensial}

Analisis inferensial dilakukan untuk mengetahui hubungan antara karakteristik pekerja dengan tingkat stres kerja yang dialami oleh pekerja. Hasil penelitian ini menunjukkan bahwa usia responden, usia anak, masa kerja dan lokasi kerja memiliki hubungan yang signifikan terhadap tingkat stres kerja (tabel 2).

Table 2. Hubungan antara Karakteristik Pekerja dengan Stres Kerja

\begin{tabular}{lcccc}
\hline & Ringan & Sedang & Berat & Pvalue \\
\hline Jenis & & & & 0,245 \\
Kelamin & & & & \\
Laki - laki & 29 & 12 & 2 & \\
Perempuan & 10 & 9 & - & \\
$\begin{array}{l}\text { Usia } \\
20-25\end{array}$ & 10 & 7 & - & 0,004 \\
$\begin{array}{l}\text { tahun } \\
26 \quad 31\end{array}$ & 11 & 11 & - & \\
\hline
\end{tabular}




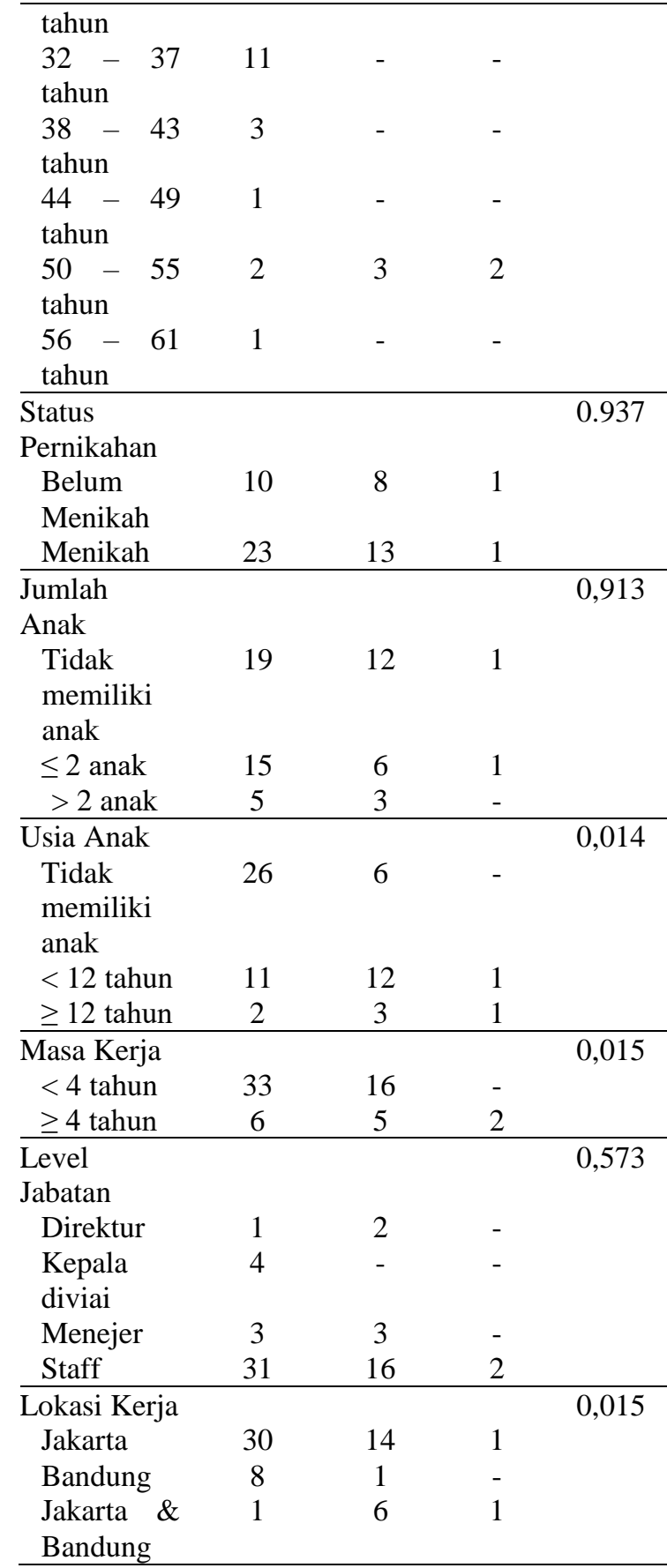

Pada tabel diatas diketahui usia responden, usia anak, masa kerja, dan lokasi kerja memiliki hubungan yang signifikan dengan stres kerja (Pvalue < 0,05). Sedangkan jenis kelamin, status pernikahan, jumlah anak, dan level jabatan tidak memiliki hubungan yang signifikan dengan stres kerja (Pvalue > 0,05).

\section{PEMBAHASAN}

\section{Hubungan jenis kelamin dengan stres kerja}

Pada tabel 2 diketahui jenis kelamin tidak memiliki hubungan yang signifikan dengan stres kerja. Hal ini dapat dikarenakan jumlah sampel yang diambil tidak seimbang antara responden laki-laki dan perempuan dan juga adanya hasil score penilaian stres kerja yang tidak terlalu signifikan antara keduanya.

Penelitian yang telah dilakukan (Awalia, Medyati, \& Giay, 2021) menunjukkan bahwasannya tidak ada perbedaan antara laki-laki dan perempuan dalam keterampilan memecahkan masalah, keterampilan analisis, dorongan untuk bekerja, motivasi, sosialitas dan kemampuan belajar. Hasil penelitian ini juga sejalan dengan penelitian (Prasastin, 2013) sebelumnya yang menyimpulkan bahwasannya tidak ada hubungan antara jenis kelamin dengan kinerja karyawan. Dimana kinerja adalah suatu pilihan komitmen yang dipilih oleh individu terlepas dari jenis kelamin individu tersebut.

\section{Hubungan usia dengan stres kerja}

Variabel umur berhubungan signifikan dengan stres kerja. Penelitian megenai usia dengan stress kerja semakin hari semakin berkembang. Hubungan antara usia dan stres kerja (Bailey \& Hansson, 1995). menunjukkan bentuk $U$ terbalik. Pertama meningkat seiring bertambahnya usia dan kemudian menurun setelah usia paruh baya. Hasilnya menunjukkan bahwa pekerja yang lebih tua menggunakan lebih sedikit metode baru dan lebih sedikit cara-cara kreatif dalam menghadapi masalah pekerjaan, dan kurang mendapat dukungan sosial dari rekan kerja dibandingkan yang lebih muda. Hal ini mengakibatkan kesehatan dan kreativitas yang menurun seiring bertambahnya usia dapat memengaruhi potensi individu untuk menghadapi tantangan kerja baru. 
Guglielmi dkk. (2016) meneliti hubungan antara tuntutan kerja terhadap kepuasan kerja, dan pekerja yang lebih muda merespon lebih baik daripada pekerja yang lebih tua. Pekerja yang lebih tua menghadapi lebih banyak stressor di tempat kerja, seperti keterbatasan kekuatan fisik serta masalah kesehatan, kesenjangan yang terkait dengan penggunaan teknologi baru, dan keterlibatan dalam pekerjaan.

\section{Hubungan status pernikahan dengan stres kerja}

Variabel status pernikahan tidak berhubungan signifikan dengan stres kerja yang dialami pekerja PT LTI. Individu yang berstatus sudah menikah biasanya memiliki tingkat stres yang lebih rendah dibandingkan dengan individu yang belum menikah. Hal ini dikarenakan adanya dukungan dalam karir dari pasangannya. Akan tetapi, pengaruh status pernikahan terhadap stres hanya akan berpengaruh positif apabila pernikahan tersebut berjalan dengan baik (Fink, 2010). Dalam penelitian ini, tidak adanya hubungan status pernikahan dengan stres kerja, bisa disebabkan karena dukungan yang diberikan pasangan tidak terlalu berpengaruh terhadap stres yang dialami pekerja.

Penelitian (Suci, 2018) menunjukkan bahwa adanya hubungan yang lemah antara status perkawinan dengan stres kerja. Hal ini dikarenakan stres kerja tidak dialami oleh semua individu yang sudah menikah. Walaupun ada tanggungjawab untuk menghidupi keluarga namun kemampuan individu untuk mengatasi hal ini membuat pekerjaannya tidak terganggu.

\section{Hubungan jumlah anak dengan stres kerja}

Kehadiran anak dalam sebuah pernikahan dianggap sebagai sesuatu yang menggembirakan bagi orangtua. Akan tetapi bagi orangtua yang bekerja, kehadiran anak akan mengakibatkan timbulnya pekerjaan tambahan dan menurunnya kepuasan pernikahan, hal ini dapat memicu terjadinya perasaat stres yang mempengaruhi kinerja karyawan di kantor (Shute, 2009).

Tidak ada hubungan yang signifikan antara jumlah anak dengan stres kerja pada pekerja PT LTI. Hal ini dapat dikarenakan jumlah responden yang tidak memiliki anak lebih banyak dibandingkan dengan responden yang memiliki anak.

Penelitian yang dilakukan Song dkk. (2019), menyatakan bahwa bagi pekerja yang tidak memiliki anak, tidak ada perbedaan antara bekerja dari rumah maupun kantor. Namun pada pekerja khususnya perempuan yang telah memiliki anak akan lebih rentan mengalami stres kerja ketika mereka melakukan pekerjaan dari rumah. Dimana fasilitas pendidikan dan penitipan anak ditutup karena adanya COVID-19.

\section{Hubungan usia anak dengan stres kerja}

Responden yang memiliki anak dengan usia $<12$ tahun lebih berisiko mengalami stres kerja dibandingkan dengan anak dengan usia $\geq 12$ tahun. Hal ini dikarenakan pekerja dengan peran ganda sebagai orang tua akan merasa sulit untuk menyeimbangkan pekerjaan dan tanggung jawab mereka sebagai orang tua, yang dimana di masa pandemic COVID-19, fasilitas pendidikan dan perawatan anak ditutup untuk sementara, sehingga menciptakan suatu dinamika baru dikehidupan. Aktivitas merawat anak merupakan salah satu aktivitas yang dapat mempengaruhi tingkat stres seseorang. Pertambahan jumlah anak juga dapat memicu terjadinya stres kerja (Sonnentag, Perrewe, \& Ganster, 2009).

Survei Eurofound (Eurofound, 2020), dari mereka yang bekerja dari rumah, $26 \%$ hidup dalam rumah tangga dengan anak di bawah 12 tahun, dan 10 persen lainnya tinggal dengan anak berusia 12-17 tahun. Para pekerja ini merasa sulit untuk menyeimbangkan pekerjaan dan tanggung jawab mereka sebagai orang tua dan hal ini berpotensi mengakibatka stres pada pekerja, dimana di masa pandemic COVID- 
19, fasilitas pendidikan dan perawatan anak ditutup untuk sementara, sehingga menciptakan suatu dinamika baru dikehidupan. Walaupun mereka mengakui bekerja dari rumah membuat mereka tidak mengalami stres ketika dalam perjalanan ke kantor, memiliki banyak waktu untuk dihabiskan bersama anak-anak dan keluarga serta adanya fleksibilitas jam kerja (International Labour Organization, 2020).

\section{Hubungan masa kerja dengan stres kerja}

Masa kerja yang lama identik dengan pengalaman yang lebih baik dan pemahaman yang lebih baik pula khususnya mengenai job description. Pengalaman dan pemahaman ini akan membantu individu untuk mengolah stressor yang diberikan. Tenaga kerja berhak mendapatkan perlindungan atas bahaya psikososial yang ada ditempat kerja, hal ini adalah salah satu upaya keselamatan dan kesehatan kerja (K3) dalam memelihara dan atau menjaga pekerjanya. Pekerja yang memiliki masa kerja yang lebih lama dapat mengalami stres kerja karena adanya rutinitas kerja yang monoton dan menimbulkan kejenuhan. Semakin lama masa kerja maka akan mempengaruhi beban kerja dan tanggungjawab. Kejenuhan timbul karena kondisi kerja yang monoton dan tidak adanya stimulus yang baru atau refreshing. Salah satu upaya yang dapat dilakukan perusahaan untuk mengontrol stres kerja yang terjadi pada pekerja adalah dengan adanya family gathering (Zulkifli, R, \& Akbar, 2019).

Uji statistic menunjukkan masa kerja memiliki hubungan yang signifikan dengan stres kerja. Sesuai dengan hasil penelitian (Munandar, 2001), masa kerja berhubungan dengan pengalaman pekerja dalam menghadapi permasalahan di tempat kerja. Masa kerja yang terlalu lama akan menimbulkan kejenuhan dalam bekerja yang berpotensi mengakibatkan stres kerja. pekerja yang telah bekerja lebih lama biasanya memiliki tingkat kejenuhan yang lebih tinggi dibandingkan dengan pekerja baru.

\section{Hubungan jabatan dengan stres kerja}

Beban kerja merupakan sesuatu yang melekat pada diri seorang pekerja sebagai suatu bentuk tanggungjawab terhadap pekerjaannya. Beban kerja yang diterima setiap pekerja akan berbeda sesuai dengan jabatannya masing-masing. Semakin tinggi jabatan, maka akan semakin tinggi pula beban kerjanya. Namun dalam beberapa penelitian terakhir, tidak membuktikan hal tersebut. Hal ini tergantung kepada bagaimana seseorang tersebut menyikapi setiap tanggungjawab yang diberikan organisasi kepadanya. Jika pekerja dapat menyikapi secara positif maka hal ini tidak berpotensi menjadi stres kerja (Arisandhi, 2017).

Dari hasil penelian ini, stres kerja berat umumnya dialami oleh level jabatan staff, yaitu sebanyak 2 responden dari 62 responden. Setelah dilakukan uji bivariate, diketahui jabatan tidak memiliki hubungan yang signifikan dengan stres kerja. Pekerja yang memiliki keputusan yang rendah terhadap pekerjaannya dan memiliki tuntutan pekerjaan yang tinggi cenderung memiliki kesehatan dan kepuasan kerja yang buruk. Hal ini berbanding terbalik dengan kelompok pekerja dengan beban kerja sedang dan control pekerjaan yang tinggi (Ahlbom, Karasek, \& Theorell, 1977). Sedangkan pada penelitian ini, level jabatan tidak berhubungan dengan stres kerja bisa terjadi dikarenakan antara tuntutan pekerjaan dengan pengambilan keputusan pada setiap level jabatan sudah sesuai dengan proporsinya masing-masing.

\section{Hubungan lokasi kerja dengan stres kerja}

Pada penelitian ini, diketahui lokasi kerja memiliki hubungan yang signifikan dengan stres. Salah satu penelitian yang dilakukan kepada guru SD untuk melihat hubungan antara demografi dan faktor pekerjaan dengan stres kerja menunjukkan tingkat stres guru yang cukup tinggi 
disebabkan oleh adanya faktor pekerjaan sedangkan demografi tidak memberikan hubungan yang signifikan (Agai-Demjaha, Minov, Stoleski, \& Zafirova, 2015). Namun dalam penelitian ini, lokasi kerja dimasukkan kedalam salah satu variabel independent dengan pertimbangan lokasi penelitian mempunyai dua kantor utama yang berbeda lokasi yaitu di Jakarta dan Bandung. Dari hasil yang didapat, lokasi kerja memiliki hubungan yang signifikan dengan stres kerja. Hal ini dapat diakibatkan, karena lokasi kantor pusat yang berada di dua lokasi mengakibatkan karyawan yang bekerja mobile JakartaBandung terkena dampaknya. Seperti adanya PSBB yang mengakibatkan karyawan tidak dapat berada di salah satu kantor pusat jika terjadi masalah, adanya penyesuaian peraturan dan juga adanya perbedaan kebijakan di dua provinsi tersebut.

Penelitian yang dilakukan oleh Utami dkk. (2021) pada pelaksanaan work from home selama masa pandemic COVID-19 di DKI Jakarta didapati bahwa paling banyak pekerja work from home di DKI Jakarta mengalami tingkat stres kerja yang normal, yaitu sebanyak $45,3 \%$ dan stres kerja berat sebanyak $5,7 \%$. Hal ini menunjukkan bahwa setiap individu memiliki strategi yang berbeda dalam menangani stres. Penanganan stres kerja dapat dilakukan dengan mengenali adanya stres, pencegahan stres, manajemen stres, dan rehabilitasi. Mengenali adanya stres pada individu dapat dilakukan dengan mengidentifikasi penyebab/ pemicu dari perubahan yang dirasakan. Pencegahan stres dapat dilakukan dengan berolahraga secara rutin. Olahraga tidak hanya membuat tubuh sehat melainkan juga membuat suasana hati menjadi lebih baik. Strategi yang baik dalam menangani stres dapat mengurangi tingkat stres pada individu.

\section{KESIMPULAN}

Kesimpulan yang dapat diambil dari penelitian ini adalah sebagian besar pekerja LTI $(62,9 \%)$ mengalami stress kerja ringan. Variabel yang berhubungan secara signifikan dengan stres kerja di LTI adalah usia responden, usia anak, masa kerja, dan lokasi kerja. Sedangkan jenis kelamin, status pernikahan, jumlah anak, dan level jabatan tidak berhubungan dengan stres pekerja di PT LTI.

\section{UCAPAN TERIMAKASIH}

Peneliti mengucapkan terimakasih kepada Allah SWT, kedua orangtua, adik, teman-teman dan dosen pembimbing akademik yang selama ini telah mendoakan dan membantu peneliti dalam menyelesaikan penelitian ini.

\section{DAFTAR PUSTAKA}

Agai-Demjaha, T., Minov, J., Stoleski, S., \& Zafirova, B. (2015). Stress Causing Factors Among Teachers in Elementary Schools and Their Relationship with Demographic and Job Characteristics. Macedonian Journal of Medical Sciences, 3, 493499.

Ahlbom, A., Karasek, R. ., \& Theorell, T. (1977). Psychosocial occupational demands and risk for cardio-vascular death. Lakartidningen, 77, 4243-4245.

Arisandhi, R. N. (2017). Hubungan Antara Beban Kerja dengan Stres Kerja pada Pegawai Bagian Tata Usaha dan Keuangan di Perusahaan Gula Kebon Agung. Universitas Islam Negeri Maulana Malik Ibrahim Malang.

Awalia, M. J., Medyati, N., \& Giay, Z. (2021). Hubungan Umur dan Jenis Kelamin dengan Stress Kerja pada Perawat di Ruang Rawat Inap RSUD Kwaingga Kabupaten Keerom. Jurnal Ilmu Sosial Dan Pendidikan, 5(2).

Bailey, L. L., \& Hansson, R. O. (1995). Psycological Obstacles to Job or Career Change in Late Life. The 
Journal Og Gerontology, 50, 280 288.

Daks, J. S., Peltz, J. S., \& Rogge, R. D. (2020). Psychological flexibility and inflexibility as sources of resiliency and risk during a pandemic: Modeling the cascade of COVID-19 stress on family systems with a contextual behavioral science lens. Journal of Contextual Behavioral Science, 18, 16-27.

Eurofound. (2020). Living, Working amd COVID-19 First Findings - April 2020. Dublin.

Fink, G. (2010). Stress Consequences: Mental, Neuropsychological, and Socioeconomic (Elsevier). United Kingdom.

Gubernur Daerah Khusus Ibukota Jakarta. (2020). Peraturan Gubernur Daerah Khusus Ibukota Jakarta No. 88 Tahun 2020 Tentang Perubahan Atas Peraturan Gubernur Nomor 33 Tahun 2020 Tentang Pelaksanaan Pembatasan Sosial Berskala Besar Dalam Penanganan Corona Virus Disease 2019 (COVID-19) di Provinsi Daerah. Jakarta.

Gubernur Jawa Barat. (2020). Peraturan Gubernur Jawa Barat no. 46 tahun 2020 tentang Pedoman Pembatasan Sosial Berskala Besar Secara Proposional Sesuai Level Kewaspadaan Daerah Kabupaten/Kota Sebagai Persiapan Pelaksanaan Adaptasi Kebiasaan Baru Untuk Pencegahan dan Pengendalian Coro. Bandung.

Guglielmi, D., Avanzi, L., Chiesa, R., Mariani, M. G., Bruni, I., \& Depolo, M. (2016). Positive Aging in Demanding Workplaces: The Gain Cycle Between Job Satis faction and Work Engagement. Fronties Psycologies, 15.

International Labour Organization. (2020). Teleworking during the COVID-19 Pandemic and Beyond; A practical Guide.

McCloskey, D. W. (2018). An examination of the boundary between work and home for knowledge workers. International Journal of Human Capital and Information Technology Professionals, 9, 25-41.

Munandar, A. S. (2001). Psikologi Industri dan Organisasi (UI Press). Jakarta.

Mungkasa, O. (2020). Bekerja dari Rumah (Working From Home / WFH): Menuju Tatanan Baru Era Pandemi COVID 19. The Indonesian Journal of Development Planning, IV(126-150).

Prasastin, O. V. (2013). Faktor-faktor yang Berhubungan dengan Kinerja Petugas Surveilans Epidemiologi Penyakit Malaria Tingkat Puskesmas di Kabupaten Kebumen Tahun 2012. Unnes Journal of Public Health, 2(4), $1-11$.

Ramadhan, G., \& Faruq, U. Al. (2020). Work From Home dan Dampaknya Bagi Pekerja Jasa Pengiriman Barang di Desa Kelurahan Pondok Karya. Pendidikan Ekonomi FKIP Universitas Pamulang, Vol 5, No, 8491.

Shute, N. (2009). Having Children Adds Stress to Marriage.

Song, Y., \& Gao, J. (2019). Does Telework Stress Employees Out? A Study on Working at Home and Subjective Well-Being for Wage/Salary Workers. Journal of Happiness Studies.

Sonnentag, S., Perrewe, P. L., \& Ganster, D. C. (2009). Current Perspective on Job Stress Recovery (Emerald Gr). United Kingdom.

Suci, I. S. M. (2018). Analisis Hubungan Faktor Individu dan Beban Kerja Mental dngan Stres Kerja. International Journal Safety and Health, 7(2), 220-229.

Utami, D., A, N. L., Andriyani, \& Fajriani, F. (2021). Gambaran Tingkat Stress Kerja dalam Pelaksanaan Work From Home Selama Masa Pandemi COVID19 di DKI Jakarta. Muhammadiyah Public Health Journal, 1(2), 101-114.

World Health Organization. (2020). 
Occupational Health: Stress at Workplaca. Retrieved November 12, 2020, from https://www.who.int/newsroom/q-a-detail/ccupational-healthstress-at-the-workplace

Zulkifli, R, S. T., \& Akbar, S. A. (2019). Hubungan Usia, Masa Kerja dan Beban Kerja dengan Stres Kerja pada Karyawan Service Well Company PT Elnusa TBK Wilayah Muara Badak. Jurnal Kesehatan Masyarakat Uwigama, 5(1), 46-61. 